\title{
To Believe or not to Believe? A College Student Explores Knowledge and Attitudes about Evolution at her School
}

\author{
Erica N. Varlese
}

Published online: 20 November 2007

(C) Springer Science + Business Media, LLC 2007

\begin{abstract}
After interviewing 17 students and four teachers at Drew University, a college of 1,400 undergraduates which I attend, I found that whereas most express a belief in evolution, many display a hesitancy to embrace the theory entirely. Instead, most students choose to believe only in evolution within lineages and not on a larger scale, specifically in the creation of new species. Teachers at the school explain that their experiences at Drew are similar to those they have experienced at other colleges they have taught at and discuss their methods for introducing the subject in the classroom and the significance of learning evolution. Furthermore, whereas it is easy for students to avoid taking biology classes that would expose them to the theory, I discuss what students look for when taking biology courses and preconceptions teachers must help students overcome when exposing them to evolution.
\end{abstract}

Keywords Evolution - Education · Drew University ·

Religion $\cdot$ Creationism $\cdot$ Intelligent designt

Drew University is a small liberal arts school in Madison, NJ, 35 miles from New York. With an undergraduate population no bigger than 1,400 and a theological seminary located right on the premises, it is home to students from all over the country, the majority of which are New Jersey

\footnotetext{
E. N. Varlese

Drew University,

36 Madison Avenue,

Madison, NJ 07940, USA

E. N. Varlese $(\bowtie)$

50 Overlook Terrace,

Bloomfield, NJ 07003, USA

e-mail: evarlese@drew.edu
}

natives, followed by New Yorkers, Pennsylvanians, and New Englanders who compose the campus community.

In my experience, the religious majority has consisted of Catholics, Protestants, and Jews, although the school was originally founded as a Methodist University, the influence of which is no longer felt, not even by the presence of a Methodist Seminary on campus.

Typical of most North Eastern colleges, the most common majors are psychology and political science, although Pre-Med students and science majors, specifically neuroscience, biology, and chemistry, are a very active presence on campus. I find that Drew is notable in the amount of academic awareness that permeates campus life. Drewids, the affectionate and unifying name Drew students like to call themselves, are almost always involved in a wide variety of extracurriculars, most commonly participating in theater productions, student government, or the student-run newspaper. Most students can often be found in their room or the library working on homework or special projects, whereas others take advantage of the proximity to New York from which the school greatly benefits. In a school where academics most often take precedence over the weekend-party culture that dominates at other colleges, one expects an intimacy with the subject of evolution above that of the national average.

In my survey, in which I questioned 17 students about their feelings about evolution and asked four professors about their experiences in the classroom, I found that Drew fell right within this middle range. Whereas only three of the students interviewed considered themselves creationists and five declared themselves evolutionists, the rest felt that they either did not know enough about the subject to make a decision or misunderstood completely the processes by which evolution worked. Whereas most proponents of evolution seem to fear attacks by creationists and Intelligent 
Designers most, I found that the middle ground these students are straddling is much more disconcerting than any extreme religious group and feel that the main cause for a willingness to accept creationism as a valid alternative to evolutionary theory is a lack of a proper understanding of the processes of evolutionary change, in addition to the refusal of many professors to state outright that Intelligent Design and religious myths are not scientifically proven and, thus, cannot be taught as alternatives to evolutionary theory.

As reported by Alters and Nelson (2002, p. 1892), a 2000 Gallup poll found that $45 \%$ of Americans believe that God created humans in their present form about 10,000 years ago and that $80 \%$ of Americans consider themselves wellinformed on the subject of evolution. Alters and Nelson (2002, p. 1892) also report that only about half of the participants in a countrywide quiz conducted by the National Science Board responded "false" when asked whether the first humans lived at the same time as dinosaurs. Later Gallup numbers do not indicate much change in recent years. In May 2006, Gallup polls (The Gallup Organization 2006) showed that $36 \%$ of Americans believe that "man developed, with God guiding" and 46 believe that "God created man in present form."

One would assume that college students would have a better grasp on basic ideas about evolution. This is clearly not the case. Alters and Nelson explain that "when students reach college, the effect of being underprepared follows them, whether or not they take any biology" (Alters and Nelson, 2002, p. 1892). They add (Alters and Nelson, 2002, p. 1892) that "classroom evolution education typically is not effective enough. A recent state-by-state evaluation of the treatment of evolution in science standards determined that (according to Lerner 2000, xii) "more than one-third of all states do not do a satisfactory job"; and, astonishingly (also according to Lerner 2000, xii), "ten [states] never use the 'E-word'." Alters and Nelson (2002, pp 1892-1893), found that of the answers university students provided on the National Science Board survey, 35\% answered that they thought early humans coexisted with dinosaurs, and that $42 \%$ stated that they did not believe human beings "developed from earlier species of animals" (Alters and Nelson, 2002, p. 1893).

As for my own experience with evolution, I recall always believing in the theory and creationism at the same time. My favorite subject in school was always science and I attended many summer school programs for children relating to biology and, later, chemistry. However, it was not until I reached the age of 10 or 11 that I began to realize that creationism could not be taken literally if I believed in evolution as well. It was a very confusing subject based on the little amount of education I had on the subject-all of the time periods of history were abstract concepts that overlapped in my young mind. It was not until I was in high school that I came across my first scientific teaching of evolution in an academic setting.

The day the evolution component of my 10th grade biology class began, my teacher announced to the classroom that evolution was a dicey subject because many people believed you could not maintain both a spiritual life and scientific belief in the theory. She, however, is a preacher's daughter and was able to overcome her own religious hesitations toward believing in evolution. Here was a successful biologist who was living proof that the long-standing dispute between religion and science could be peaceably resolved. She was able to study, in-depth, the theory of evolution, while maintaining a strong bond with her family and actively participating in her religious community.

Before this introduction, I had hardly discussed evolution in my years of Catechism and by the time I reached 9th grade, I was already in the beginning of a period of intense religious skepticism. Nevertheless, the more I research and talk to people about the subject of evolution in the classroom, the more I realize how unique my unbiased and conciliatory introduction was.

As my Drewid peers explained their views on evolution to me over the past month, what I found was more disconcerting than I expected. I was surprised to find such a large amount of students who filled the gaps in their evolutionary education with religious myths or creationist rhetoric. The first few students I interviewed are deeply religious and only believe "partially" in evolution, explaining that they feel "humans developed, but [not] . . . from apes." This intensified my distress and I feared that my college, whose mission statement emphasizes both breadth and depth in education, was actually dominated by religious thought. Nevertheless, I found that this sort of cherry-picking of evolutionary tenets is very common, even from students who identify as "not very religious." Other students explained that they "don't not" believe in evolution and felt they do not "know enough about it to make a real decision." One such student, a freshman Humanities major, explained that she can "see religion in everyday life. But evolution, it just doesn't really affect me."

Overall, it appears that the anthropology students have the best grasp of the processes of evolution, mentioning theories of punctuated equilibrium and stating that it is not that evolution is "just a theory," as many other students declared, but that it is a theory in the scientific sense of the term, meaning it has been tested and proven repeatedly. It was only the process by which it occurred that was cause for debate within the scientific community, they told me.

One sophomore Pre-Med student in particular lamented about a Christian science club that hosted a discussion on evolution last year. "I stopped going because I was the only 
one there that believed and everyone else said it was "just a theory."

The religion with which a student aligns him or herself plays a major part in how he or she views evolution. For the most part, it is only the Christian religions that polarize the debate. Of the Jewish students I interviewed, five in total, all believed fully in evolution, although they were able to sustain their systems of religious belief and spirituality. One such student, a freshman biological anthropology major said, "I consider myself a humanistic Jew-I don't take the Torah word for word. I have my own relationship with God and I believe there has to be a reason for evolution," leaving the reason for evolution open to a spiritual explanation.

As to whether or not creationism should be taught in conjunction with evolution, most Christian religious students stated that an acknowledgment of their beliefs made them feel more open to hearing about evolution. Nevertheless, these same students stated that in their introductory biology courses, the teachers did speak about creationism, and that they resent that they taught evolution "as a given." One such student, a sophomore religious studies major, was afraid to take an evolution course because she felt her teachers would "look down on her" because of her beliefs.

The students who firmly believe in evolution and who have not experienced any cognitive dissonance in accepting scientific reasons for human evolution and still maintained their religious principles felt that teaching creationism in the classroom sounds too "defensive" and that it has "no place in schools because it's a completely religious theory with no empirical evidence."

Interestingly enough, no student denied the importance of learning evolution. Even the creationists felt that it was important to learn "all sides of the issue." Many students were insecure in their answers because they felt they did not know enough, although almost all had learned a limited amount of evolution in high school biology classes in both public and religious schools.

Except for four students, all of those interviewed did not know their parents' beliefs on evolution, stating that they "never really discussed it." Of those four, two said their belief in evolution was in agreement with their parentsone student, a sophomore political science major, said that his father is a scientist who admires Darwin greatly and there was always a "presence of Darwin" in his home. The other two, however, differed greatly from their parents. One, a junior biology major and creationist, said her father "definitely believed in evolution" and that he was not really spiritual. The other student, a freshman English major, is the daughter of a preacher, and both of her parents are very religious. "I went to Bible school every Sunday and if I missed church, I had to watch cartoons of the gospel," she said, adding that she had purposefully avoided taking any courses on evolution so she did not have to "challenge her faith." After completing a human evolution course as a requirement for her archeology minor, she said she is "fascinated" by the subject and that it appeals to both her "spiritual and logical sides."

In terms of course requirements, it is quite easy for many students to avoid taking courses relating to evolution. One sophomore psychology major has not taken any biology courses since high school and is not planning on taking any more.

This lack of education intensifies the problem and promotes the belief in popular misconceptions. An anthropology professor that specializes in biological anthropology courses stated that there were three main misconceptions she encountered when teaching students about evolution. The first, she said, was that you could not be religious and believe in evolution. The second was the idea that you have to "teach the controversy." Lastly, she said, many creationist students believe that there are some intrinsic "gaps" in the theory, rendering it false - to which she exclaimed, "What gaps?", further comparing the argument to the markings on a ruler. "It's analogous to saying that the fact that there are gaps on a ruler between the one-eighth inch marks implies that linear measurement doesn't exist," she said.

Each professor interviewed, including two biology professors in addition to the anthropology professor, described their experiences at other colleges as not very different than Drew. They all stated that they never had problems with teaching evolution in terms of administrative opposition to their planned courses. For the most part, students who did not believe in evolution only expressed dissent at the end of the courses on the teacher evaluation forms and each had their anomalies, including one student who wrote on the final exam in the anthropology professor's evolution course that he would "pray she found Jesus."

These reactions, however, were the exception, even at other institutions. One of the biology professors previously taught at the Indiana University and found that it was "pretty much similar" to Drew. Another biology professor, who has been teaching for 15 years, began as a teaching assistant at Duke and later moved on the Notre Dame, where she had "no problems," despite the school's Catholic affiliation. The anthropology professor, however, had a notable experience at Baylor University in Texas, where she offered an introductory anthropology course to students who were becoming missionaries. A student approached her and explained that he was "concerned about his soul" because he would have to answer questions about evolution on the teacher's exam. The professor and the student discussed the problem, coming to the conclusion that he could provide the answer he thought she would want, while writing "but I don't believe this" in the margins. The professor stated that he found no need to write it once throughout the exam. 
Drew University has no historical record of evolution controversies. The main issue the college faces now is educating its students to bring them above the national average. I was disappointed not by the amount of creationist science majors that I found, but by the large majority of students that were sitting on the fence: neither evolutionists nor creationists, but poorly educated moderates. Evolution and religion can indeed coexist; the two subjects provide the answers to very different questions in mutually unobtrusive ways. It is when students fill in the gaps of their science education with religion and popculture hearsay that we really need to become concerned. As one professor said, "If a person is already convinced, you can't change their minds," a statement validated by the numerous cases of students who took biology and evolution courses but refused to see the evidence, constantly searching for gaps in reasoning and criticizing the small number of fossil remains that evolutionary biologists use to try to reconstruct the human species' past.

I find it is the students that say they believe only in evolution within a lineage and that "you will never know how the human species came about anyway" that are most troubling. This is the majority of America and the majority of Drew University, a school that I do not think is much different from other liberal arts colleges in the nation. If so many students can go through college without gaining a proper understanding of evolutionary theory and the grounds for believing it, they will be ill-equipped throughout the rest of their lives.

The evolutionary theory is not only valuable in the context of biological studies, but as both biology professors said, it allows graduates to become educated citizens. Their knowledge of evolution will affect their decisions regarding AIDS, the use of antibiotics, and many other hot-topic issues in society today. The provost of Drew University, a biologist, said, "As a teacher, I'm obligated to teach that which is as far as we know to be correct. The evidence for evolution is becoming greater and it's getting harder and harder to deny."

If these "in-between"-ers are not addressed, the Gallup poll scores will never improve and America will remain at half its potential. Rather than validate creationism as an alternative, teachers must explain that a belief in evolution is not contradictory to their spirituality. Dispel the misconceptions. Refute the "gaps" and teach them how we can discover so much from a mandible, a leg bone or even a tooth. Do not let students pick and choose-teach them without compromise about the processes of evolution, including the origin of species. Then we will be on the right track for an evolution of the education system.

\section{References}

Alters BJ, Nelson CE. Perspective: teaching evolution in higher education. Evolution 2002;56:10 1891-1901

The Gallup Organization. The Gallup poll: evolution, creation, and intelligent design. 2006; <http://www.galluppoll.com/content/ default.aspx?ci=21814>

Lerner, LS. Good science, bad science: teaching evolution in the States. Thomas B. Fordham Foundation: Washington D.C.; 2000. 